\title{
SQUALUS APPENDICULATUS.
}

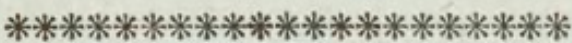

CHARACTER GENERICUS.

$\mathrm{O}_{s}$ in anteriore et inferiore capitis parte, dentibus numerosis seriatis.

Spiracula utrinque ad latera colli, plerisque quinque.

Corpus oblongum, teretiusculum.

CHARACTER SPECIFICUS, ${ }^{\circ}$.

SQUALUS fuscus, maculis subocellatis pallidis, ore utrinque appendiculis cutaneis fimbriato.

Watts's Shark.

Phill. V. to Bot. Bay, p. 285.

In minimis sui generis numeratur hæc species. Raro longitudinem tripedalem exuperavere specimina quæ adhuc reperta sunt. Generant Squalum appendiculatum maria Antarctica. 



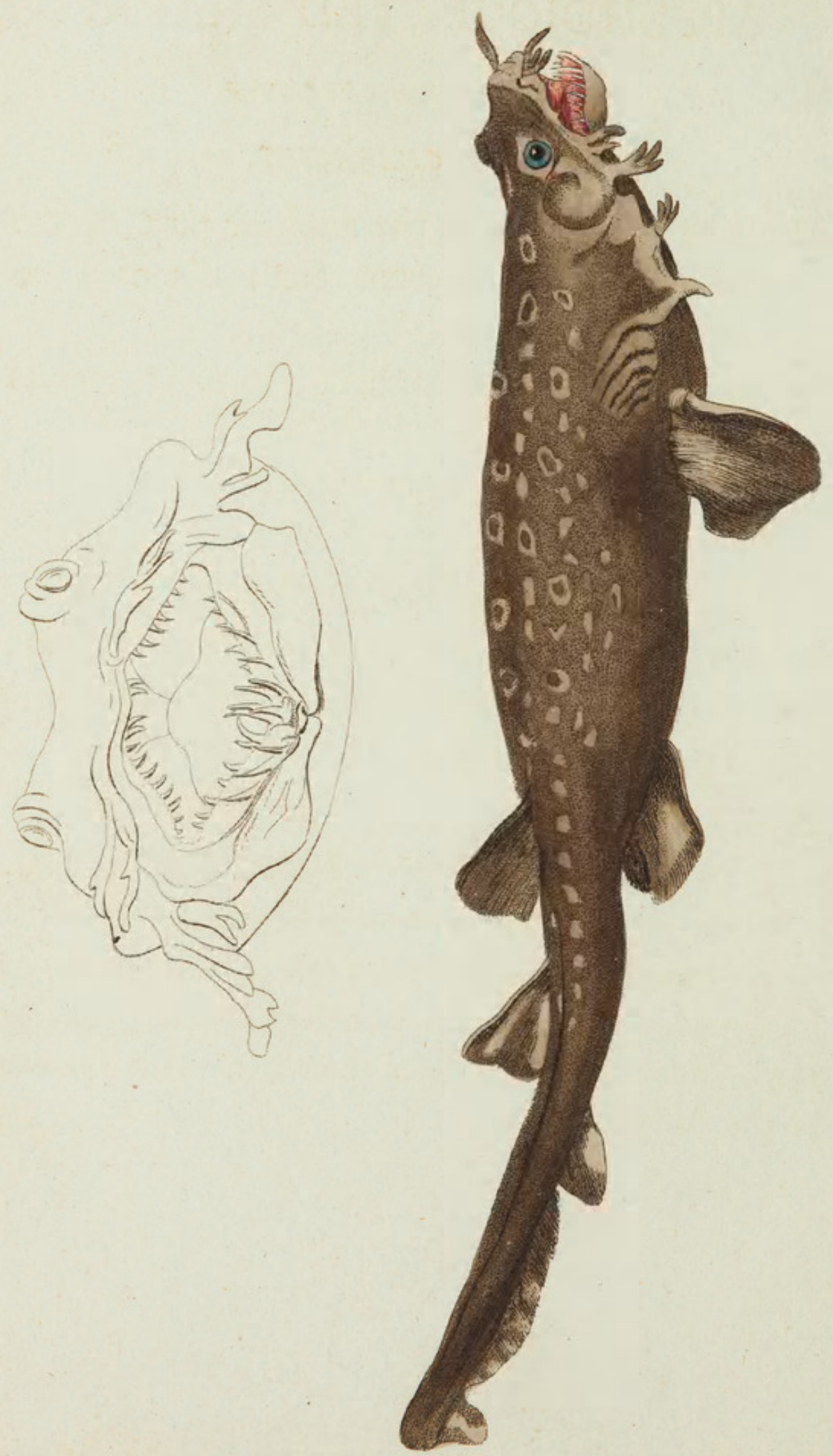
THE

\section{APPENDICULATED SHARK.}

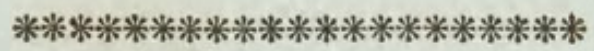

GENERIC CHARACTER.

Mouth situated beneath the anterior part of the head, with numerous teeth disposed in rows.

Spiracles on each side the neck, in most species five in number.

Body oblong, somewhat cylindric.

SPECIFIC CHARACTER, Ec.

Brown SHARK, with pale subocellated spots, and mouth fringed on each side with cutaneous appendages.

Watt's SHARK.

Phillips's Voyage to Botany Bay, p. 285.

This species is considered as one of the smallest of its genus, the specimens hitherto observed, having rarely exceeded the length of three feet. It is a native of the Antarctic seas. 


\section{$2 \mathrm{BHL}$ Biodiversity Heritage Library}

Shaw, George. 1805. "The Appendiculated Shark, Squalus appendiculatus [PI. 727]." The Naturalist's Miscellany 17(CXCVI), https://doi.org/10.5962/p.311164.

View This Item Online: https://www.biodiversitylibrary.org/item/281954

DOI: https://doi.org/10.5962/p.311164

Permalink: https://www.biodiversitylibrary.org/partpdf/311164

\section{Holding Institution}

Museums Victoria

\section{Sponsored by}

Atlas of Living Australia

\section{Copyright \& Reuse}

Copyright Status: Public domain. The BHL considers that this work is no longer under copyright protection.

This document was created from content at the Biodiversity Heritage Library, the world's largest open access digital library for biodiversity literature and archives. Visit BHL at https://www.biodiversitylibrary.org. 